\title{
ВЛИЯНИЕ ПАССИВНОГО КУРЕНИЯ НА МИКРОЭЛЕМЕНТНЫЙ СТАТУС АМНИОТИЧЕСКОЙ ЖИДКОСТИ В ЭКСПЕРИМЕНТЕ
}

\author{
О.В. Мариинская ${ }^{1,2} *$, Т.В. Казакова ${ }^{1,2}$, С.В. Нотова ${ }^{1,2}$, Л.В. Лизурчик ${ }^{2,3}$ \\ ${ }^{1}$ Федеральный научный центр биологических систем и агротехнологий РАН, г. Оренбург, Россия \\ ${ }^{2}$ Оренбургский государственный университет, г. Оренбург, Россия \\ ${ }^{3}$ ГАУЗ ООКБ №2 Перинатальный Центр, г. Оренбург, Россия \\ *e-mail: m.olja2013@yandex.ru
}

РЕЗЮМЕ. Микроэлементы являются компонентами многочисленных регуляторных ферментов и гормонов, необходимых для деления и дифференцировки клеток плода и их дальнейшего развития. В связи с этим целью исследования явилось изучение влияния пассивного курения на микроэлементный статус амниотической жидкости. Для проведения эксперимента было отобрано 40 половозрелых самок крыс Wistar, из которых сформированы две группы (контрольная и опытная). Животные опытной группы подвергались воздействию пассивного курения, контрольную группу составили интактные животные. Оценка элементного статуса осуществлялась посредством изучения химического состава амниотической жидкости методами ИСП-АЭС и ИСПМС в лаборатории АНО «Центр биотической медицины» (Москва). Установлено, что воздействие табачной интоксикации оказало влияние на содержание микроэлементов амниотической жидкости. Концентрации Са, Fе и $\mathrm{P}$ в амниотической жидкости животных опытной группы были достоверно ниже, содержания данных элементов у крыс контрольной группы на 20,9, 74,2 и 60,9\% соответственно.

КЛЮЧЕВЫЕ СЛОВА: микроэлементы, пассивное курение, амниотическая жидкость.

\section{THE INFLUENCE OF PASSIVE SMOKING ON THE MICROELEMENT STATUS OF THE AMNIOTIC FLUID IN THE EXPERIMENT}

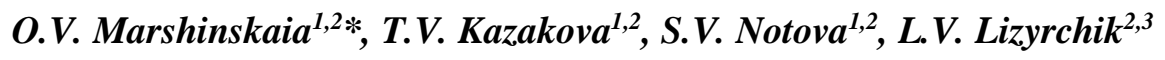 \\ ${ }^{1}$ Federal Research Centre of Biological Systems and Agrotechnologies RAS, Orenburg, Russia \\ ${ }^{2}$ Orenburg State University, Orenburg, Russia \\ ${ }^{3}$ Regional Clinical Hospital №2 Perinatal Centre, Orenburg, Russia \\ *e-mail: m.olja2013@yandex.ru
}

ABSTRACT. Trace elements are components of numerous regulatory enzymes and hormones necessary for the division and differentiation of fetal cells and their further development. In this regard, the aim of the study was to study the effect of passive smoking on the microelement status of amniotic fluid. For the experiment, 40 mature females of the Wistar line were selected, of which 2 groups were formed (control and experimental). The animals of the experimental group were exposed to passive smoking, the control group consisted of intact animals. The elemental status was assessed by studying the chemical composition of the amniotic fluid using the ICP-AES and ICP-MS methods in the laboratory of the ANO "Center for Biotic Medicine", Moscow. The study found that exposure to tobacco intoxication had an effect on the content of trace elements in the amniotic fluid. The concentration of $\mathrm{Ca}, \mathrm{Fe}$, and $\mathrm{P}$ in the amniotic fluid of the experimental animals was significantly lower by $20.9 \%, 74.2 \%$, and $60.9 \%$, respectively.

KEYWORDS: trace elements, passive smoking, amniotic fluid.

\section{ВВЕДЕНИЕ}

Табакокурение в настоящее время является одной из наиболее распространенных в мире привычек, наносящих вред здоровью человека и обществу в целом (Wang et al., 2018). Под действием никотина происходят нарушения ряда обменных процессов в организме, в том числе и минерального обмена, ведущего к дисбалансу биоэлементов и, как следствие, к развитию различных патологий. Амниотическая жидкость является биологически активной средой, окружающий плод, что обеспечивает нормальное функционирование системы мать-плацента-плод (Kocylowski et al., 2019). В амниотической жидкости накапливаются продукты обмена веществ плода, кислород и углекислый газ, гормоны и ферменты (Jacob et al., 2017). Микроэлементы являются компонентами многочисленных регуляторных 
ферментов и гормонов, необходимых для деления и дифференцировки клеток плода и их дальнейшего развития.

Цель исследования - изучение влияния пассивного курения на микроэлементный статус амниотической жидкости.

\section{МАТЕРИАЛЫ И МЕТОДЫ}

Для проведения эксперимента было отобрано 20 половозрелых самок крыс Wistar из которых сформированы две группы (контрольная и опытная). Контрольная группа на протяжении всего эксперимента ежедневно находилась в течение 30 мин 2 раза в день в затравочной камере при отсутствии табачного дыма. Животные опытной группы находились в равных условиях при ежедневном 30-минутном воздействии табачного дыма в затравочной камере 2 раза в день. Каждое животное получало 0,048 мг никотина в день.Оценка элементного статуса осуществлялась посредством изучения химического состава амниотической жидкости методами ИСП-АЭС и ИСП-МС в лаборатории АНО «Центр биотической медицины» (Москва). Обработку полученных данных проводили при помощи методов вариационной статистики с использованием статистического пакета «StatSoft STATISTICA 10». Применялись непараметрические процедуры обработки статистических совокупностей (U-критерий Манна- Уитни).

\section{РЕЗУЛЬТАТЫ И ОБСУЖДЕНИЕ}

Важным показателем обмена веществ между матерью и плодом является изучение минерального обмена. В проведенном эксперименте концентрации $\mathrm{Ca}, \mathrm{Fe}$ и $\mathrm{P}$ в амниотической жидкости животных опытной группы были ниже на $20,9,74,2(p \leq 0,01)$ и $60,9 \%(p \leq 0,05)$ соответственно. Железо является необходимым микроэлементом для построения гемоглобина и миоглобина и является неотъемлемой частью цитохромов и окислительно-восстановительных ферментов. Снижение железа, наряду с кальцием и фосфором, может свидетельствовать о недостаточной функции плаценты.

\section{ВЫВОДЫ}

Амниотическая жидкость демонстрирует неоднозначную ответную реакцию организма на воздействие негативных внешних факторов, в частности табачной интоксикации на систему «мать-плод». Полученные данные косвенно свидетельствуют о токсическом воздействии изучаемого фактора, который может привести к плацентарной недостаточности, гипотрофии и незрелости внутриутробного развития организма плодов.

\section{Сиисок литературы / References}

1. Wang B., Zhu Y., Pang Y., Xie J., Hao Y., Yan H., Li Z., Ye R. Indoor air pollution affects hypertension risk in rural women in Northern China by interfering with the uptake of metal elements: A preliminary cross-sectional study. Environmental Pollution. 2018; 240: $267-272$.

2. Kocylowski R., Grzesiak M., Gaj Z, Lorenc W., Bakinowska E., Baratkiewicz D., von Kaisenberg C.S., Lamers Y., Suliburska J. Associations between the Level of Trace Elements and Minerals and Folate in Maternal Serum and Amniotic Fluid and Congenital Abnormalities. Nutrients. 2019; 11(2): 328.

3. Jacob N., Golmard J.L., Berlin I. Fetal exposure to tobacco: nicotine and cotinine concentration in amniotic fluid and maternal saliva. J Matern Fetal Neonatal Med. 2017; 30(2): 233-239. 